\title{
The vegetation of the farms Ingleside and Welgedacht of the Mountain Zebra National Park, Eastern Cape
}

\section{L.R. BROWN and H BEZUIDENHOUT}

Brown, L.R. and H Bezuidenhout. 2005. The vegetation of the farms Ingleside and Welgedacht of the Mountain Zebra National Park, Eastern Cape. Koedoe 48(2): 23-42. Pretoria. ISSN 0075-6458.

South Africa is well known for its semi-arid lowland areas that have a distinct flora and species composition. Because ecosystems react differently to different management practices, it is important that a description and classification of the vegetation of an area be done. As part of a vegetation survey programme for the newly acquired farms incorporated into the Mountain Zebra National Park, the vegetation of the Ingleside and Welgedacht sections were surveyed following the Braun-Blanquet approach. From a TWINSPAN classification, refined by Braun-Blanquet procedures, 10 shrub and grassland plant communities, which can be grouped into seven major groups, were identified. A classification and description of these communities, as well as a vegetation map are presented. The diagnostic species as well as the prominent and less conspicuous species of the tree, shrub, herb and grass strata are outlined. The area generally comprises lowland communities and higher-lying communities. The lower-lying communities consist mainly of two communities and comprise the largest proportion of the area in hectares. In contrast, the higher-lying communities are more diverse with specific habitats. Using the Ecological Index Method the veld condition and grazing capacity were calculated for each community and the total study area. Large sections of the lowland areas are overgrazed due to previous farming grazing practices while the higher-lying areas that were less accessible to the animals are in a slightly better condition. Overall this has resulted in the area generally being degraded within a high grazing capacity of 30.1 ha/LSU.

Keywords: Braun-Blanquet, plant communities, TWINSPAN, vegetation classification, veld condition, grazing capacity.

L.R. Brown $\varangle$, Applied Behavioural Ecology \& Ecosystem Research Unit, Department of Nature Conservation, UNISA, Private Bag X6, Florida, 1710 Republic of South Africa; H Bezuidenhout, Arid Ecosystems Research Unit, Conservation Services, SANParks, P.O. Box 110040, Hadison Park, Kimberley, 8306 Republic of South Africa.

\section{Introduction}

The prevention of the increasing loss of biodiversity is a daunting challenge facing the world today. Humans continuously alter their environment to suit their needs resulting in a large number of ecosystems being destroyed every year. South Africa is richly endowed with endemic plant and animal species and is the third most biologically diverse county in the world (Hall-Martin 2003). The establishment of protected areas within which large ecosystems are conserved, is increasingly seen as a solution to the prevention of ecosystem loss. However, to be able to conserve our natural resources for the current and future generations, it is important that the different ecosystems be studied and managed on a scientific basis.

South Africa has a well-established system of National Parks situated within the various biomes to protect and manage the ecological integrity of the different ecosystems for present and future generations. One such Park, the Mountain Zebra National Park (MZNP) was established in 1937 to protect the Cape Mountain Zebra (Equus zebra zebra) popula- 
tion that at that time numbered only 11 (Brown \& Bezuidenhout 2000). The size of the park was too small to sustain a viable population of these animals resulting in the park area being extended in 1964 (Carruthers 2003). Since 1996, the park size was again extended and various farms adjacent to the park have been procured or are in the process of being bought and incorporated into the park. These new areas have not only resulted in the park more than doubling its size from its previous 6536 ha, to approximately 21000 ha, but include new ecosystems and make the re-introduction of various large mammals such as Cape buffalo, black rhino and gemsbok possible.

Because ecosystems react differently to different management practices (Bredenkamp 1982; Bezuidenhout 1993), it is important that a description and classification of the vegetation of an area is undertaken (Van Rooyen et al. 1981). Vegetation is the most physical representation of an ecosystem. Any change in the ecosystem (pollution, development, grazing, droughts) is first observed in changes in the vegetation. It is therefore of utmost importance that vegetation is studied in detail to determine species and population composition in order to compile an inventory of the flora. This will not only enable us to sustainably manage and protect our natural resources, but also to determine linkages between ecosystems and detect any changes in the environment. It is widely recognised that a detailed description, identification, classification and mapping of the vegetation forms the basis for sound land-use planning and management (Tueller 1988; Fuls et al. 1992; Fuls 1993; Bezuidenhout 1996, Brown 1997).

Although extensive studies on various aspects of the vegetation of the current MZNP have been conducted by Van der Walt (1980), Novellie (1990a, 1990b) and Novellie \& Bezuidenhout (1994), little is known about the vegetation and habitat status of these newly acquired areas. The main aim of this study was therefore to describe and map the plant communities of the Welgedacht and Ingleside farms, which have already been acquired by the South African National Parks.

This study forms part of a larger and longterm research project undertaken by South African National Parks and UNISA. The aim of this project is to describe and map the vegetation of each of the new farms and assess the habitats of these areas for the establishment of large herbivores. This will enable management of the MZNP to take scientifically based decisions on the management of each of these areas before incorporating it into the larger MZNP area. All the data will then be incorporated into the existing management plan for the MZNP.

\section{The study area}

The MZNP is situated approximately $12 \mathrm{~km}$ west from the town of Cradock in the Eastern Cape Province. It extends from latitude $32^{\circ} 05^{\prime}-32^{\circ} 20^{\prime} \mathrm{S}$ and longitude $25^{\circ} 23^{\prime}-25^{\circ}$ 32 'E (Fig. 1). The park is situated within the Nama-Karoo Biome. This biome is the second largest biome of South Africa and occupies the hotter, drier, western half of the inland plateau of South Africa. Though extending to areas as low as $500 \mathrm{~m}$ asl, it mostly lies between 1000-4000 m asl (HallMartin 2003). The park is situated in a transitional zone between the arid karoo bushveld of the western and central karoo and the drier more palatable grassveld in the east (Van der Walt 1980). According to Acocks (1988), the area can be classified as False Karroid Broken Veld (37), whereas Hoffman (1996) classifies it as Eastern Mixed Nama Karoo (52). Some isolated patches of the South-eastern Mountain Grassland (Grassland Biome) (Lubke et al. 1996) are also found in the park. The low rainfall of these areas ensures that the predominant soil type of this biome is lime-rich and prone to erosion (Hall-Martin 2003).

The Welgedacht and Ingleside sections (study area) comprise 1554 ha and lie approximately $11 \mathrm{~km}$ north of the previously proclaimed section of MZNP. The study area borders onto the previously described De 


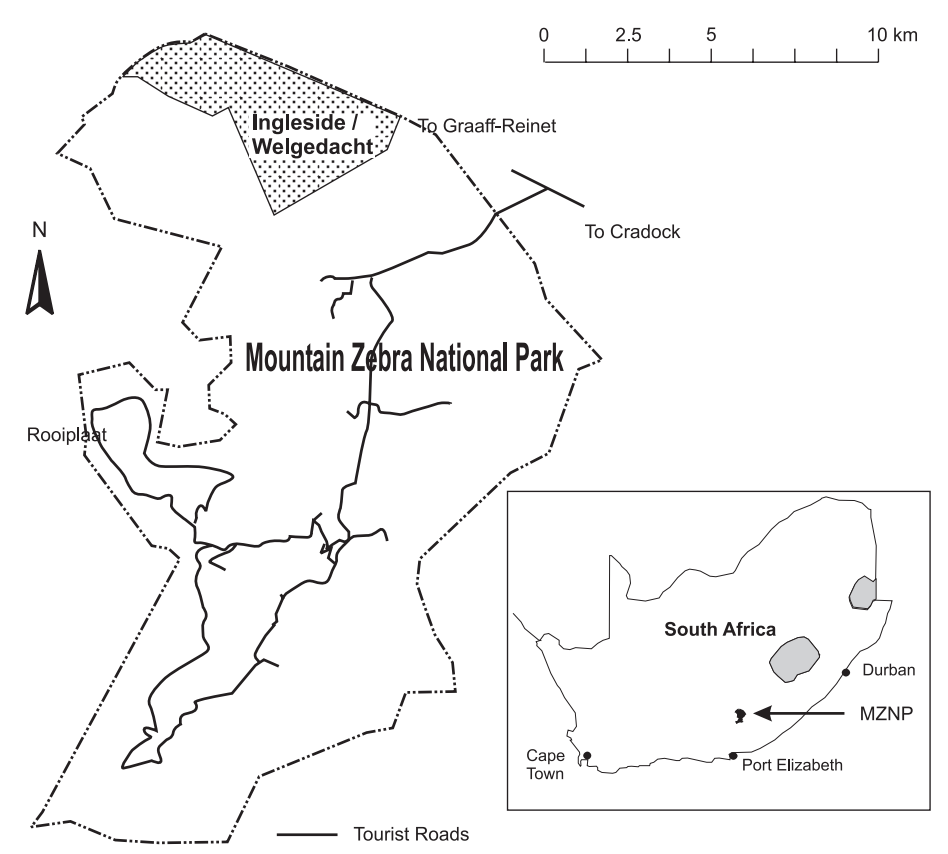

Fig. 1. Location of the study area.

Rust section (Brown \& Bezuidenhout 2000) of the MZNP in the west (Fig. 1). The northern part is bound by the main road to Graaff Reinet. The dominant vegetation is a mixture of grassy, dwarf shrubland with trees usually occurring along drainage lines and dominated by only one or two species (Van der Walt 1980).

The northern and eastern areas of the study area comprise lower lying valley bottomlands and dry riverbeds, together with flat to undulating plateau sections. The southwestern section comprises steep to moderately steep mountain slopes of the Salpeterkop Mountain which is also the most prominent geological feature of the study area.

\section{Land types with references to the} physiography, geology and soil

Three land types, namely Ag, Ib and Fc occur in the study area. According to the Land Type Survey Staff (1986) "A land type denotes an area that can be shown at
1:250 000 scale and that displays a marked degree of uniformity with respect to terrain form, soil pattern and climate”. A remarkable association between the major plant communities and the different land types has been observed in other studies (Kooij et al. 1990; Bezuidenhout 1993; Eckhardt 1993; Brown 1997).

The land type unit Ag refers to red apedal, freely drained, high base status soil, which is shallower than $400 \mathrm{~mm}$. The predominant geology of this land type is mudstone, shale and sandstone of the Balfour Formation, Beaufort Group of the Karoo Supergroup (Toerien 1972). A dense subdendritic drainage and dissection pattern occurs in this land type with some dolerite intrusions. The slightly undulating plains are dominated by the valley bottomland terrain unit with Hutton the dominant soil form (Soil Classification Working Group 1991). This soil is shallow (150-400 mm), rocky, and the sand grade is fine (Land Type Survey Staff 1999). 


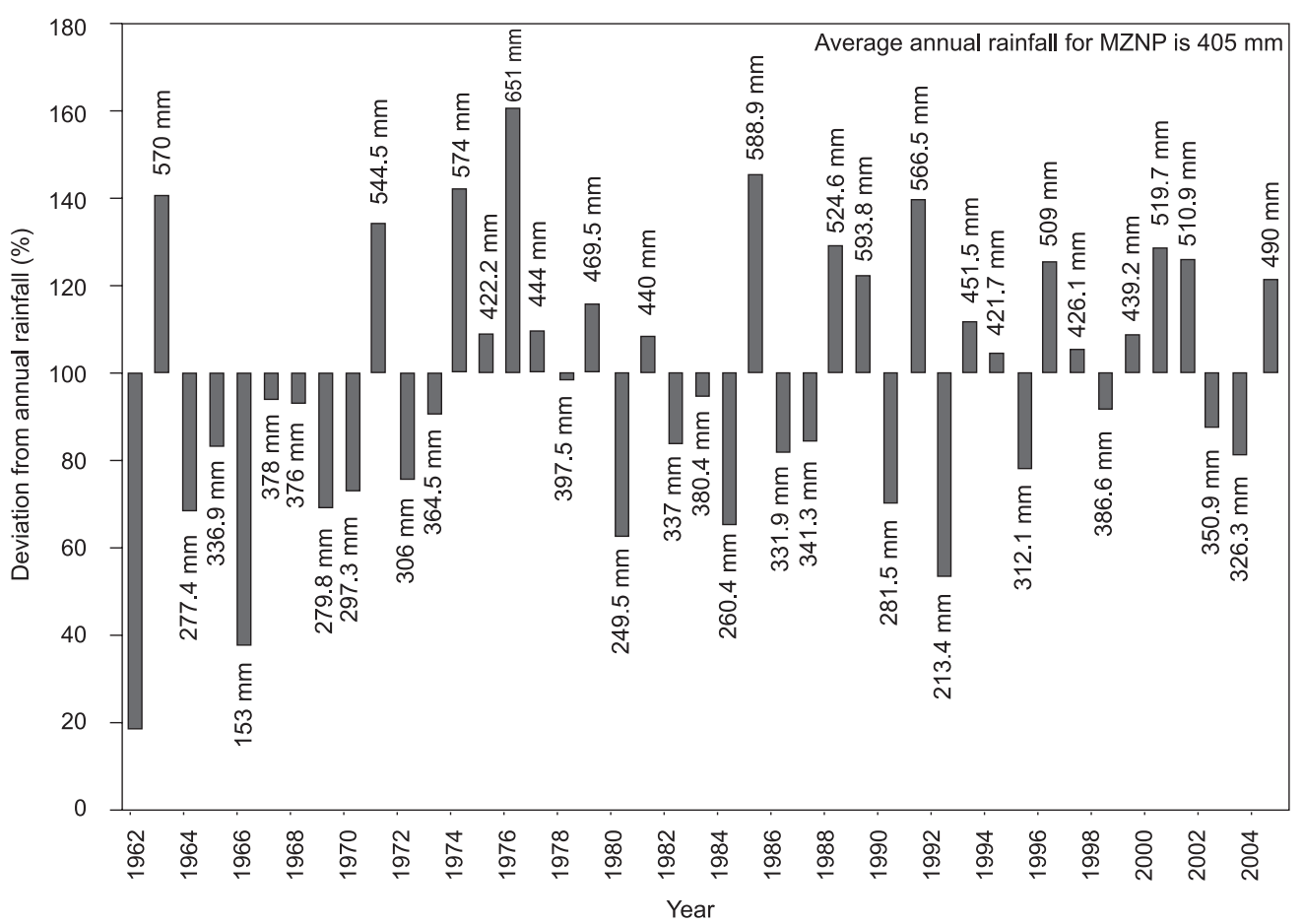

Fig. 2. Percentage deviation from average annual rainfall at Mountain Zebra National Park between 1962 and 2004. (Rainfall year = Jan. to Dec.)

The $\mathrm{F}$ land type refers to pedologically young landscapes which are predominantly rocky and not alluvial or aeolian. The Fc unit refers to land where lime occurs regularly in upland and valley bottomland soil (Land Type Survey Staff 1986). Soil forms that epitomise this land type are Glenrosa and Oakleaf. The geology consists of mudstone, shale and sandstone of the Beaufort Group of the Karoo Supergroup with rare dolerite intrusions (Land Type Survey Staff 1999). Two topographical positions are prominent in this terraced landscape, namely the footslopes and valley bottomlands.

The Ib land type unit refers to exposed rocks that cover $60-80 \%$ of the area. The rocky portions of Ib may be underlain by soil which has qualified the unit for inclusion in another broad soil pattern had it not been for the surface rockiness. The midslopes are the most prominent topographical position in this mountainous landscape and the dominant soil-rock complex consists of rock while the Glenrosa soil form is subdominant. The geology consists of dolerite with mudstone, shale and sandstone of the Balfour Formation, Beaufort Group of the Karoo Supergroup (Land Type Survey Staff 1999).

\section{Climate}

The average annual rainfall for the area, as measured at the MZNP weather station from July 1962 to June 2004, is $405 \mathrm{~mm}$ with the highest rainfall of $651 \mathrm{~mm}$ and lowest rainfall of $153 \mathrm{~mm}$ being recorded in 1976 and 1966, respectively. The general rainfall trend from 1962-2004 shows an increase in aver- 
age annual rainfall since 1962 . There is no increase in rainfall amplitude but rather a decrease in rainfall extremes (Fig. 2). This is also illustrated in the higher average annual rainfall of $424.5 \mathrm{~mm}$ for the past 10 years. The lowest rainfall recorded for this 10-year period was $213.4 \mathrm{~mm}$ (1992) and the highest $565.5 \mathrm{~mm}$ (1991). The average monthly rainfall varies from $11.3 \mathrm{~mm}$ in the dry winter season to $60.8 \mathrm{~mm}$ in the wet summer season (Brown \& Bezuidenhout 2000).

The average maximum temperature varies between $23.11-28.4^{\circ} \mathrm{C}$ in summer (September-March) and $16.2-22.7^{\circ} \mathrm{C}$ in winter (April-August), whereas the average minimum temperature varies between 5.6$13.6^{\circ} \mathrm{C}$ in summer and $0.05-7.8^{\circ} \mathrm{C}$ in winter (Fig. 3) (Brown \& Bezuidenhout 2000).

\section{Methods}

Plant communities are conceived as types of vegetation recognised by their floristic composition. The full species composition of the different communities expresses their relationship to each other and the environment better than any other characteristic (Westhoff \& Van der Maarel 1978). In order to accomplish a detailed vegetation survey of the study site the area was stratified into physiognomic-physiographic units using 1:50 000 stereo aerial pho-

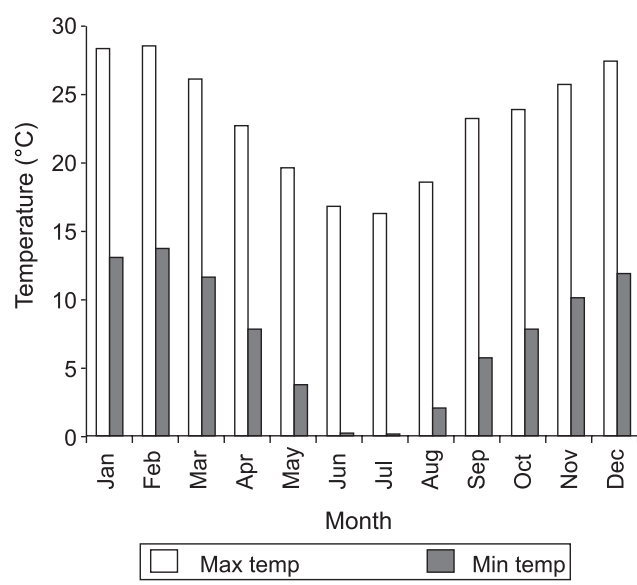

Fig. 3. The mean average minimum and maximum temperatures for Mountain Zebra National Park. tographs. After a reconnaissance of the area sample plots were randomly located within the different homogeneous units identified from the aerial photographs. The number of sample plots allocated within each homogeneous unit depended on the size of the area, the larger the area the higher the number of sampling plots allocated to the unit. A total of 52 sample plots were randomly located within these units to ensure that all variations in the vegetation were considered and sampled. Plot sizes were fixed at approximately $400 \mathrm{~m}^{2}$ according to Brown (1997) and Brown \& Bezuidenhout (2000).

Veld condition and grazing capacity were determined for each community. The Ecological Index Method (Foran et al. 1978; Vorster 1982; Smit 1988), which has proved successful for formulating management practices, was used (Orban 1995).

After the percentage grass and forb species composition for each sample site was calculated, the species were classified into ecological categories, namely Decreasers, Increasers I, IIa, IIb and IIc species, according to their reaction to utilisation (Danckwerts 1989; Trollope et al. 1990). With only few exceptions, the ecological status of the grasses conforms to that used by Van Oudtshoorn (1992) while all forbs and/or herbaceous weeds were classified as Increaser IIc species. The data was then incorporated into a model (GRAZE) used to calculate the grazing capacity. This model was developed by Bredenkamp (Ecotrust cc) and is described in Brown (1997) who successfully applied it in the Borakalalo Nature Reserve, North-west Province.

\section{Sampling}

Total floristic composition was noted for every sample plot. Making visual estimates, sampling was done by means of the Braun-Blanquet method (Mueller-Dombois \& Ellenberg 1974). Braun-Blanquet cover abundance values were assigned to all plant species encountered in the relevés (Table 1).

Plant species identification was done according to Germishuizen \& Meyer (2003). Soil classification is according to the Soil Classification Work Group (1991). Trees and shrubs were distinguished from each other using the guidelines set by Edwards (1983). Trees are classified as rooted, woody, selfsupporting plants $>3 \mathrm{~m}$ high with one or a few definite trunks and shrubs are classified as rooted, woody, self-supporting, multi-stemmed or singlestemmed plants $<3 \mathrm{~m}$ high (adapted from Edwards 1983). A minimum of 200 and a maximum of 600 step points depending on community size were done within each plant community to determine veld condition score. 
The habitat conditions including geology, soil forms and other edaphic factors, slope, aspect and the rockiness of the soil surface, of each relevé, were qualitatively described. This information was used in the description of the different plant communities. The coordinates of each relevé was determined and noted with the use of a GPS.

\section{Data processing}

The floristic data was analysed according to BraunBlanquet procedures using the BBPC suite (Bezuidenhout et al. 1996). The numerical classification program TWINSPAN (Hill 1979), which is regarded as a successful approach for classification by several phytosociologists (Mucina \& Van der Maarel 1989; Bredenkamp \& Bezuidenhout 1995; Cilliers 1998) was used to derive a first approximation of the floristic data. Further refinement of the classification was achieved by Braun-Blanquet procedures (Bredenkamp et al. 1989; Kooij et al. 1990; Bezuidenhout 1993; Eckhardt 1993; Brown \& Bredenkamp 1994). Using the phytosociological table and the habitat information gathered during the sampling period, the different plant communities were identified and described. Plant communities were recognised by using diagnostic species as defined by Westhoff \& Van der Maarel (1978). Diagnostic/ character species are those that are largely restricted to a community. These species do not necessarily have a high importance value. The different plant communities are described according to their dominant species. Dominant species are those that are most conspicuous in the community and are high in one or more of the importance values (Whittaker 1978), in this case cover and frequency. No attempt was made to formally fix syntaxa names as this is normally avoided in detailed local studies (Coetzee 1983). This will only follow after extensive studies on savanna vegetation in South Africa to prevent synonymy of syntaxa names. Uncommon species not diagnostic for any of the communities are not included in the table, but are available upon request from the corresponding author.

\section{Results}

\section{Classification}

The results are presented in a phytosociological table (Table 1). The analysis resulted in the following ten plant communities (Fig. 4), which may be grouped into seven major community types:

1. Buddleja glomerata-Rhus lucida Shrubland

2. Carissa macrocarpa-Cenchrus ciliaris Shrubland.

2.1 Euclea undulata-Carissa macrocarpa Shrubland

2.1.1 Portulacaria afra Variant

2.1.2 Euclea undulata Variant

2.2 Rhus lucida-Carissa macrocarpa Shrubland

3. Setaria neglecta-Becium burchellianum Grassland

4. Rhigozum obovatum-Enneapogon scoparius Grassland.

5. Panicum maximum-Acacia karroo Woodland.

6. Eragrostis obtusa-Pentzia globosa Shrubland

6.1 Tragus koelerioides-Pentzia globosa Shrubland

6.2 Cynodon incompletus-Pentzia globosa Shrubland

7. Chloris virgata-Cynodon incompletus Grassland

\section{Description of the plant communities}

In the descriptions of the different plant communities, all species groups refer to Table 1 while the veld condition index and grazing capacity values are given in Table 2 . Therefore no repeated reference will be made to Tables $1 \& 2$ in the descriptions of the various plant communities.

\section{Buddleja glomerata-Rhus lucida Shrubland.}

This community is situated in the southwestern section on the escarpment and cliffs at the top of the Salpeterkop Mountain. The altitude was measured at $1432 \mathrm{~m}$ above sea level, while the very steep eastern slopes ranges between 25-28 . Rock cover varies between 55-90\% with the plant species growing between rocky outcrops and in rock crevices. This community is only 16 ha in extent.

The cover of the woody layer varies between 15-40 \%, and the herbaceous layer between 30-50\%. The woody layer comprises shrubs varying in height between 1.8-2.2 m while the herbaceous layer varies between 0.3-0.6 $\mathrm{m}$ in height. 


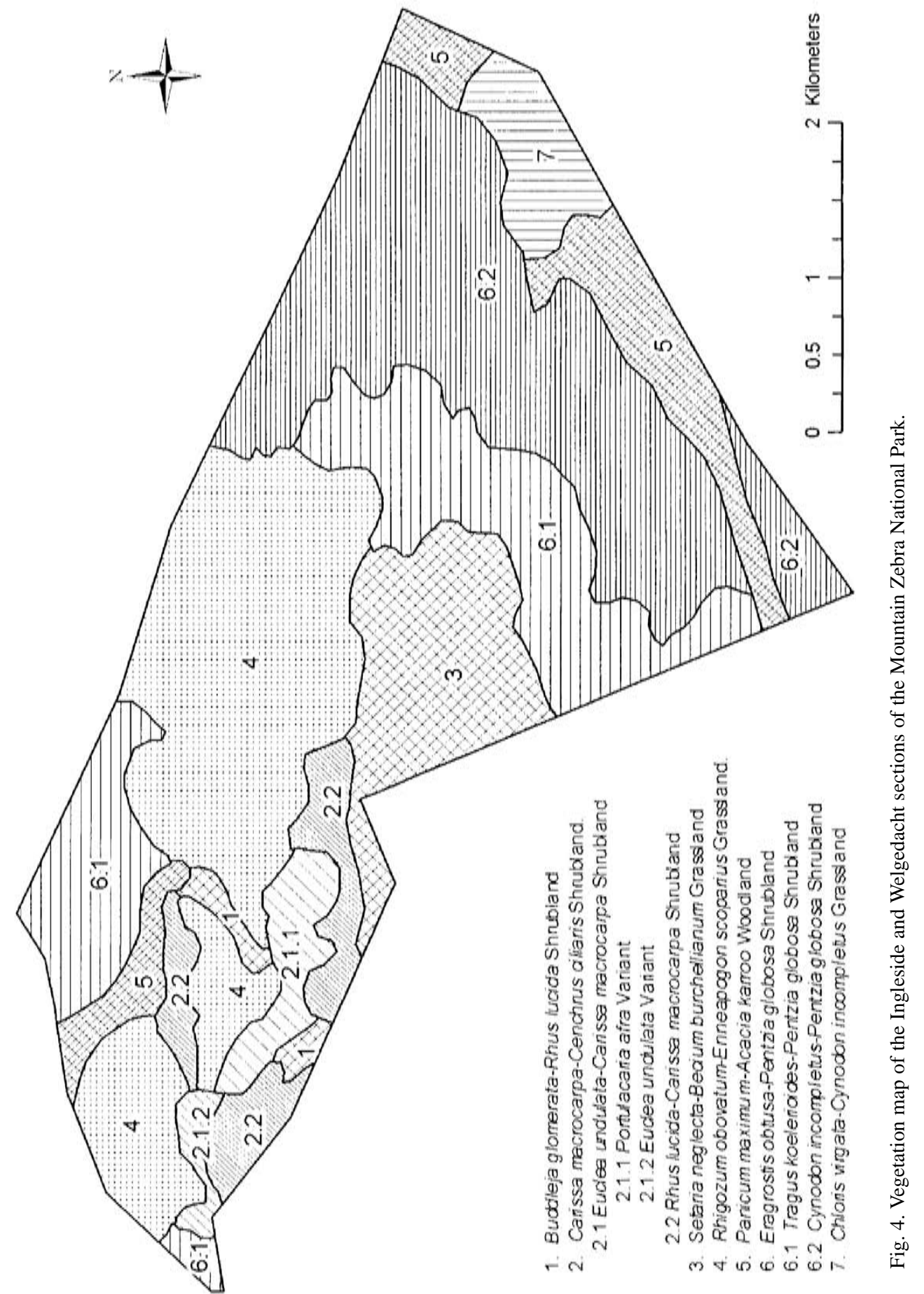


The diagnostic species include the shrubs Buddleja glomerata, Ehretia rigida and the forbs Ceterach cordata, Hermannia vestita and Hibiscus species (species group A).

The vegetation is dominated by the shrubs Rhus lucida (species group F) and Buddleja glomerata (species group A). Other species also prominent locally include the shrubs Rhus longispina, Grewia occidentalis (species group $\mathrm{J}$ ), and the grasses Aristida junciformis (species group F) and Cenchrus ciliaris (species group J).

This community shows affinity with the Rhus lucida-Buddleja glomerata Shrubland described by Brown \& Bezuidenhout (2000) in the De Rust section and the Buddleja glomerata-Rhus lucida Woodland described by De Klerk et al. (2003) in the Ebenaeser section of the MZNP. No veld condition data were collected within this community due to the inaccessibility of the area to animals and because the largest section is situated on cliffs.

2. Carissa macrocarpa-Cenchrus ciliaris Shrubland.

This shrubland comprises 136 ha and is found on the steep northern and western midslopes of the Salpeterkop Mountain. The altitude varies between 1115-1400 m asl with large rocks covering the soil. Rock cover is high varies between $50-70 \%$.

Tree cover is estimated at between $2-4 \%$, while the shrub stratum covers between $15-40 \%$ of the area. The herbaceous cover is estimated at between 5-60 \%. The average tree height varies between $3.5-4 \mathrm{~m}$, while the average height of the shrubs is $2.5 \mathrm{~m}$. The herbaceous layer is approximately $0.5 \mathrm{~m}$ tall.

This community is characterised by the presence of the shrub Carissa macrocarpa, the grass Bothriochloa insculpta and the forb Galenia species (species group B).

Although these species are diagnostic for this community, they are locally prominent in the Rhigozum obovatum-Enneapogon scoparius Grassland (community 4). This com- munity can be divided into the following two sub-communities:

\subsection{Euclea undulata-Carissa macrocarpa Shrubland}

The Euclea undulata-Carissa macrocarpa Shrubland is situated on the steep northern and western midslopes of the Salpeterkop Mountain. Altitude varies between 1124$1304 \mathrm{~m}$ asl. The shrubland is covered with large rocks with an approximate 70 \% coverage.

The shrub layer is well developed and the most prominent layer within this sub-community, whereas the tree and herbaceous layers are not well developed with low cover.

The shrub Euclea undulata and the grass Setaria verticilata (species group C) are diagnostic for this sub community.

The vegetation is dominated by the shrub Euclea undulata (species group C), whereas the shrubs Rhigozum obovatum, Rhus longispina, Grewia occidentalis and the grass Cenchrus ciliaris (species group J) are prominent locally.

\subsubsection{Portulacaria afra Variant}

This variant (42 ha) is found on the higher northern midslopes of the Salpeterkop Mountain in the southern section of the study area. Altitude varies between 1226-1304 m above sea level. The area comprises large to medium sized rocks covering approximately $70 \%$ of the area. There is no soil between these rocks resulting in no herbaceous vegetation occurring between the rocks.

The tree layer is approximately $3.5 \mathrm{~m}$ tall with a $3 \%$ cover. The shrub layer is the most prominent layer varying in height between 2-2.5 m with a 35-40 \% cover. The herbaceous layer $(0.2 \mathrm{~m})$ is poorly developed with a 5-18\% cover.

The tree Boscia oleoides and the tall shrub Portulacaria afra (species group D) are diagnostic for this variant. Although also present in the Buddleja glomerata-Rhus luci- 
da Shrubland (community 1), the presence of the forb Cyphostemma quinatum (species group E) together with the diagnostic species (species group D) is characteristic for this community.

The vegetation is dominated by the shrub Euclea undulata (species group C), whereas the grass Cenchrus ciliaris (species group J) is prominent in the herbaceous layer underneath trees where there is some soil present. The tall shrub Portulacaria afra (species group D) is very dense and dominant locally. Other species prominent locally include shrubs Rhigozum obovatum and Grewia occidentalis (species group J). The tree Lycium oxicarpon (species group L), the dwarf shrub Asparagus suaveolens and the grass Tragus koelerioides (species group Q) are also present.

This community is inaccessible to most game species due to the large rocks with no soil in-between covering the area. Thus no veld condition was calculated for this small community and it was not taken into account when determining the grazing capacity for the study area.

\subsubsection{Euclea undulata Variant}

This variant is found on the higher western midslopes of the Salpeterkop Mountain in the southern section of the study area though slightly lower than the Portulacaria afra Variant (2.1.1) with the altitude varying between $1124-1140 \mathrm{~m}$ asl. This variant is only 14 ha in size and comprises large boulders to medium sized rocks covering approximately $70 \%$ of the area.

The trees are taller than $4 \mathrm{~m}$ and have an estimated $5 \%$ coverage while the shrub layer (2.5-3 m tall) is the most prominent layer of this community with an 18-25\% cover. The herbaceous layer covers between $5-15 \%$ of the area and is between $0.2-0.3 \mathrm{~m}$ tall.

This variant is distinguished from the Portulacaria afra Variant (community 2.1.1) by the absence of species from species groups $\mathrm{D}$ and $\mathrm{E}$.
The vegetation is dominated by the shrubs Carissa macrocarpa (species group B) and Euclea undulata (species group C). The shrub Rhus longispina is prominent locally. The tree Acacia karroo (species group L) and the grass Panicum maximum (species group $\mathrm{K}$ ) are also present throughout this variant.

The woody layer of this variant has previously been heavily utilised by Angora goats with browsing line effects clearly visible. The veld condition and grazing capacity for this variant were calculated at $48 \%$ and 41.4 ha/LSU, respectively.

\subsection{Rhus lucida-Carissa macrocarpa Shrubland}

This shrubland comprising 80 ha is found on the steep northern and north-western midslopes of the Salpeterkop Mountain with slopes ranging between $15^{\circ}$ and $21^{\circ}$. Altitude varies from $1115-1400 \mathrm{~m}$ asl with large rocks covering $50-60 \%$ of the area.

The woody layer is not very prominent with the trees ( $<4 \mathrm{~m}$ tall) covering only $2 \%$ and the shrubs (1.5-2.5 $\mathrm{m}$ tall) covering between 15-20\% of the area. The herbaceous layer (0.5-0.7 $\mathrm{m}$ tall) is the most prominent layer covering between $50-60 \%$ of the area.

The presence of the shrub Rhus lucida, the grasses Themeda triandra, Aristida junciformis, Sporobolus fimbriatus and the forb Pegolettia retrofracta (species group F) together with the shrub Carissa macrocarpa, the grass Bothriochloa insculpta and the forb Galenia species (species group B) are characteristic for this community.

The shrub Rhus longispina (species group J) dominates the woody layer, while the grass Cenchrus ciliaris (species group J) dominates the herbaceous layer. The shrubs Rhus lucida (species group F), Rhigozum obovatum (species group J) and the grasses Themeda triandra and Aristida junciformis (species group F) are also prominent.

This community is in good condition with certain sections slightly degraded due to pre- 


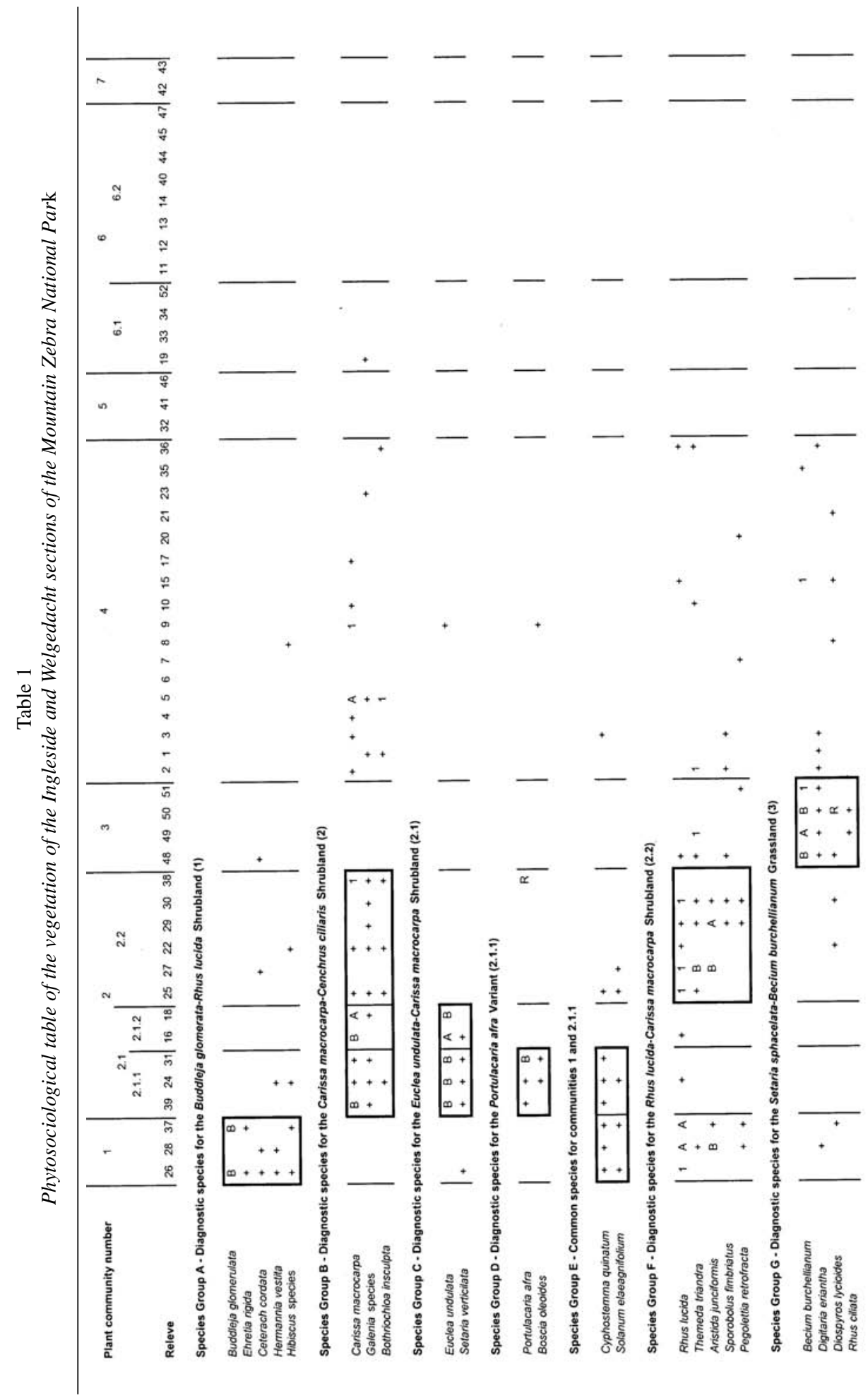




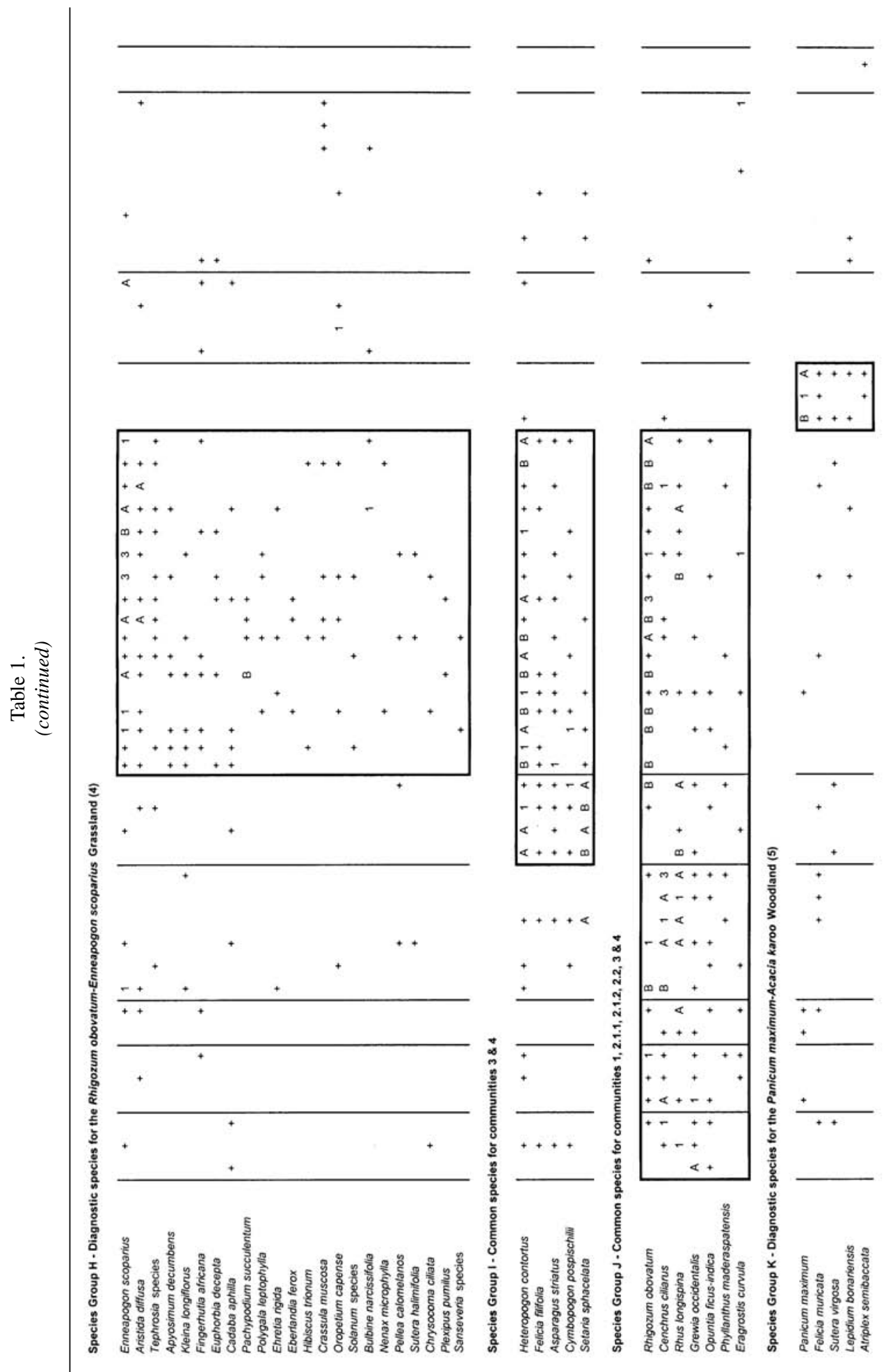




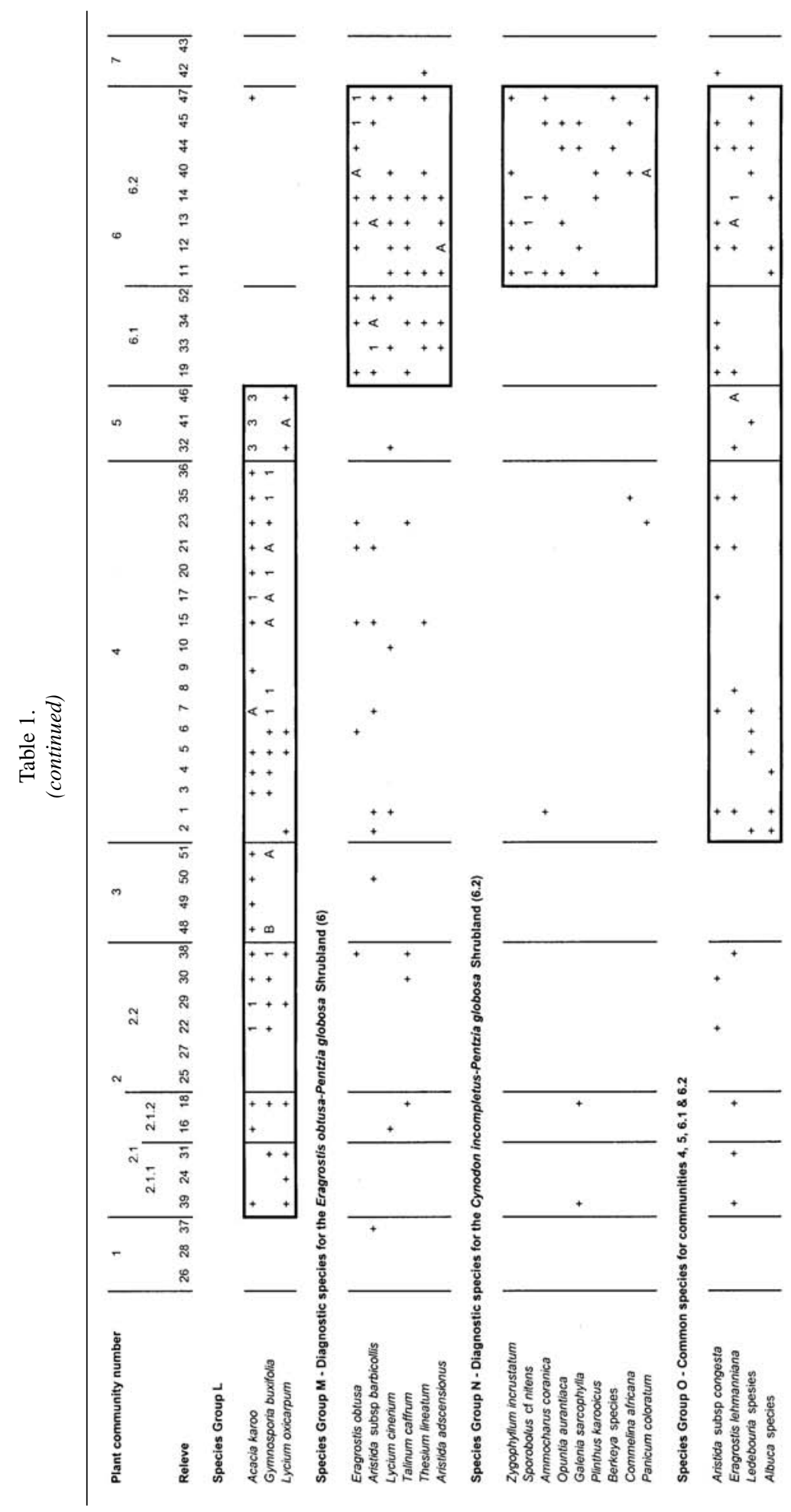




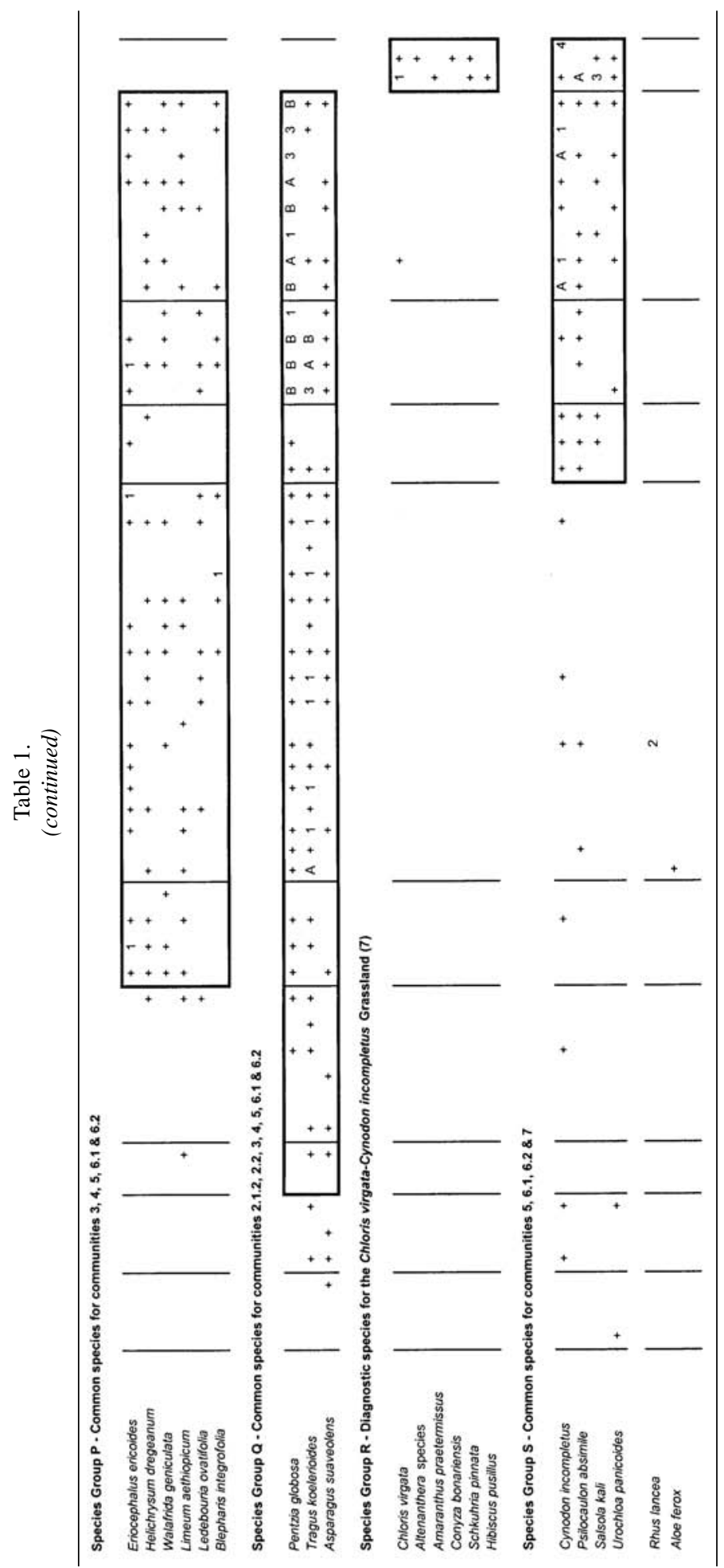


Table 2

Veld condition and grazing capacity for Ingleside and Welgedacht farms, Mountain Zebra National Park

\begin{tabular}{lccccccccccc}
\hline Plant community & 1.0 & 2.1 .1 & 2.1 .2 & 2.2 & 3.0 & 4.0 & 5.0 & 6.1 & 6.2 & 7.0 & Total \\
\hline $\begin{array}{l}\text { Size (ha) } \\
\begin{array}{l}\text { Veld Condition } \\
\text { Index (\%) }\end{array}\end{array}$ & 16.0 & 42.0 & 14.0 & 80.0 & 148.0 & 383.0 & 129.0 & 272.0 & 415.0 & 55.0 & 1554.0 \\
$\begin{array}{l}\text { Grazing capacity } \\
\text { (ha/LSU ) }\end{array}$ & 0.0 & 0.0 & 48.4 & 93.1 & 55.4 & 35.7 & 28.5 & 22.2 & 32.5 & 19.7 & \\
$\begin{array}{l}\text { Number LSU } \\
\text { Game }\end{array}$ & 0.0 & 0.0 & 0.3 & 4.0 & 9.7 & 13.6 & 5.0 & 4.0 & 12.2 & 0.8 & 49.7 \\
\hline \begin{tabular}{l} 
Total Grazing Capacity (ha/LSU) Game \\
\hline
\end{tabular}
\end{tabular}

vious grazing practices. Owing to the abundance of the palatable grass Cenchrus ciliaris this community achieved a high veld condition score of $93 \%$ and a grazing capacity of 20 ha/LSU. The steep slopes on which it is located makes this community inaccessible to plains game species and it will therefore not be utilised frequently by game. If incorrectly managed this community could change into a dense thicket.

\section{Setaria neglecta-Becium burchellianum Grassland}

This Grassland is found on the eastern midslope plateaus and lower midslopes of the Salpeterkop Mountain in the centre of the study area. The altitude varies between 1099-1144 m asl with large rocks covering $25-50 \%$ of the area. The midslope plateaus are level though the lower midslopes are moderate to steep varying from $8^{\circ}$ to $15^{\circ}$. This grassland is 148 ha in size.

There is no tree layer. The shrub layer varies in height between 1.5-2.5 m with a $10 \%$ cover. The herbaceous layer $(0.4-0.6 \mathrm{~m}$ tall) is the most prominent layer and covers between $30-60 \%$ of the area.

Diagnostic species include the shrub Diospyros lycioides, dwarf shrub Rhus ciliata, the grass Digitaria eriantha and the forb Becium burchellianum (species group G).
This grassland is dominated by the grasses Setaria sphacelata and Heteropogon contortus (species group I), and the forb Becium burchelliatum (species group $\mathrm{G}$ ). The shrubs Rhus longispina, Rhigozum obovatum (species group J) and Eriocephalus ericoides (species group P) are prominent locally. Other species also present include the dwarf shrubs Asparagus striatus, Felicia filifolia (species group I), Pentzia globosa (species group Q), the grass Cymbopogon pospischilii (species group I) and the forbs Helichrysum dregeanum and Walafrida geniculata (species group P).

This area has previously been mildly utilised by domestic animals and does not show signs of severe overgrazing. The veld condition score for this community is $55 \%$ resulting in it having a grazing capacity of $15.3 \mathrm{ha} / \mathrm{LSU}$.

\section{Rhigozum obovatum-Enneapogon scoparius Grassland}

The Rhigozum obovatum-Enneapogon scoparius Grassland is the second largest community on the study area (383 ha). It is located on midslopes and footslopes and sometimes on mid-plateaus in the northern and western sections of the study area. The area has small to large rocks with a 30-60\% cover. Altitude varies between 1053-1215 m above sea level. 
There are only a few trees (3.5 m tall) present covering approximately $3 \%$ of the area. The shrub layer consists mainly of dwarf shrubs and a few larger shrubs ranging between $0.5 \mathrm{~m}$ and $2 \mathrm{~m}$ tall with a 15-30\% cover. The grasses are between $0.2-0.4 \mathrm{~m}$ tall with a 15-50 \% cover.

This community is characterised by the presence of species from species group $\mathrm{H}$. These include the shrubs Cadaba aphylla, Ehretia rigida, the dwarf shrub Eberlanzia ferox, Chrysocoma ciliata, the grasses Enneapogon scoparius, Aristida diffusa, Fingerhuthia africana, Oropetium capense and the forbs Tephrosia species, Aptosimum decumbens, Kleinia longiflorus, Euphorbia decepta, Pachypodium succulentum, Polygala leptophylla, Hibiscus trionum, Crassula muscosa, Solanum species, Bulbine narcissifolia, Nenax microphylla, Pellaea calomelanos, Sutera halimifolia, Plexipus pumilus and Sansevieria species.

The vegetation is dominated by the shrubs Rhigozum obovatum (species group J) and Gymnosporia buxifolia (species group L) together with the grasses Enneapogon scoparius (species group $\mathrm{H}$ ) and Heteropogon contortus (species group I). The following species are locally prominent: the tree Acacia karroo (species group L), the shrub Rhus longispina (species group $\mathrm{J}$ ), the grasses Aristida diffusa (species group H), Cymbopogon pospischilii (species group I), Cenchrus ciliaris (species group J), Tragus koelerioides (species group Q) and the forbs Pachypodium succulentum (species group $\mathrm{H})$ and Blepharis integrifolia (species group P).

This community is accessible to game and domestic animals. As a result it has been heavily overgrazed due to previous farming practices and has a veld condition index of only $36 \%$ resulting in a grazing capacity of $28.1 \mathrm{ha} / \mathrm{LSU}$.

\section{Panicum maximum-Acacia karroo Woodland}

The Panicum maximum-Acacia karroo Woodland is situated in the valley bottom- land drainage channels in the south-east and western sections of the study area comprising 129 ha. Altitude varies between 1022$1077 \mathrm{~m}$ asl. Rock cover is low varying between 1-3\% though in one section it has been estimated at $20 \%$.

The trees are taller than $5 \mathrm{~m}$ and cover between $10-25 \%$ of the area, while the shrub layer ( $2 \mathrm{~m}$ tall) covers between $15-35 \%$ of the area. The herbaceous layer with an average height of $0.7 \mathrm{~m}$ has a 30-60 \% cover.

The vegetation is characterised by the presence of the diagnostic species of species group $\mathrm{K}$ and include the grasses Panicum maximum and the forbs Felicia muricata, Sutera virgulosa, Lepidium bonariensis and Atriplex semibaccata.

The woody layer is dominated by the tree Acacia karroo (species group L), while the herbaceous layer is dominated by the grass Panicum maximum (species group $\mathrm{K}$ ). The shrub Lycium oxicarpon (species group L), the dwarf shrub Psilocaulon absimile (species group S) and the grasses Eragrostis lehmaniana (species group $\mathrm{O}$ ) and Cynodon incompletus (species group S) are locally prominent.

This community consists of various drainage channels flowing into each other. The vegetation of this community is disturbed due to previous overgrazing and trampling resulting in various erosion gulleys in and along the drainage channels. This disturbance is evident in the poor condition of the veld $(28.5 \%)$ and low grazing capacity of $25.6 \mathrm{ha} / \mathrm{LSU}$. Animals prefer this community throughout the year because of the presence of the palatable tree Acacia karroo and the palatable grass Panicum maximum. This normally leads to this community being heavily utilised by animals.

\section{Eragrostis obtusa-Pentzia globosa Shrubland}

This community is found on the lower footand midslopes of the Salpeterkop Mountain in the eastern and northern section of the study area. Altitude varies between 1017- 
1099 m asl with small rocks and gravely soil. Rock cover is low and varies between 0-30\%. This major community with a total size of 687 ha comprises $44 \%$ of the study area.

The vegetation consists mainly of grasses and dwarf shrubs with no tree layer present. The dwarf shrubs have an average height of $0.3 \mathrm{~m}$ and covers between $25-30 \%$ of the area while the grasses are between $0.1-0.3 \mathrm{~m}$ tall with a 25-60\% coverage.

This shrubland is characterised by species group $\mathrm{M}$ and include Eragrostis obtusa, Aristida congesta subsp. barbicollis, Aristida adscensionis and the forbs Lycium cinerium, Talinum caffrum and Thesium lineatum.

The vegetation is dominated by the dwarf shrub Pentzia globosa (species group Q) while the grasses Eragrostis obtusa and Aristida congesta subsp. barbicollis (species group $\mathrm{M}$ ) are also prominent.

\subsection{Tragus koelerioides-Pentzia globosa Shrubland}

This largest section of this sub-community is located in the eastern section and the north western sections of the study area on the lower midslopes of the Salpeterkop Mountain. Altitude varies between 1063-1099 m above sea level. Rock cover varies between 25-60 \% with shallow soil. This is the third largest community of the study area and is 272 ha in size.

This community is characterised by the absence of species from species group $\mathrm{N}$. The vegetation has been heavily grazed resulting in an average height of $0.2 \mathrm{~m}$ for the dwarf shrubs covering between 15-20\% of the area while the grasses are between $0.1-0.2 \mathrm{~m}$ tall with a 5-10\% coverage.

The vegetation is dominated by the dwarf shrub Pentzia globosa and the grasses Tragus koelerioides (species group Q) and Aristida congesta subsp. congesta (species group M). The grass Enneapogon scoparius (species group $\mathrm{H}$ ) are locally prominent while the dwarf shrub Asparagus suaveolens (species group Q) are present throughout the community.

This shrubland is heavily overgrazed and degraded (the north western sections particularly) with a low species diversity mainly comprising pioneer species. This severe overgrazing of this sub-community is reflected in the very low veld condition of $22.2 \%$ and grazing capacity of 68.3 ha/LSU.

\subsection{Cynodon incompletus-Pentzia globosa Shrubland}

The Cynodon incompletus-Pentzia globosa Shrubland is the largest single community of the study area comprising 415 ha. This shrubland is located in the eastern footslopes and midslopes of the Salpeterkop Mountain on deeper and more fertile soil. Altitude varies between 1017-1083 m asl while rock cover is low and varies between $0-10 \%$.

This community is characterised by the presence of the diagnostic species of species group $\mathrm{N}$ and include the dwarf shrubs Zygophyllum incrustatum, Plinthus karooicus, the grasses Panicum coloratum, Sporobolus nitens, the forbs Opuntia aurantiaca, Galenia sarcophylla, Berkeya species Commelina africana and the geophyte Ammocharis coranica.

The vegetation is dominated by the dwarf shrub Pentzia globosa (species group Q) and the pioneer grass Cynodon incompletus (species group S), whereas the grasses Eragrostis obtusa, Aristida congesta subsp. congesta (species group M), Sporobolus nitens (species group N) and Eragrostis lehmaniana (species group $\mathrm{O}$ ) are also prominent.

The declared invader Opuntia aurantiaca (species group $\mathrm{N}$ ) is present in large numbers in sections within this community and should be eradicated. A fairly large number of termite mounds characterise this shrubland. This sub-community has also been prone to overgrazing and has a veld condition score of $32.5 \%$ and a grazing capacity of 34.1 ha/LSU. 


\section{Chloris virgata-Cynodon incompletus Grassland}

This community is situated on old cultivated fields in the lower lying areas in the western section of the study area and is only 55 ha in size. The area is level and the altitude was measured at $1023 \mathrm{~m}$ above sea level. There are only a few small rocks present covering less than $1 \%$ of the area.

There is no woody layer present and the herbaceous layer is $0.2 \mathrm{~m}$ tall and covers between $40-80 \%$ of the area.

The grass Chloris virgata and the forbs Altenanthera species, Amaranthus praetermissus, Conyza bonariensis, Schkuhria pinnata and Hibiscus pusillus (species group R) are diagnostic for this community.

The vegetation comprises a mixture of various pioneer species dominating sections locally. These include the grasses Cynodon incompletus (species group S), Chloris virgata (species group R) and the forb Salsola kali (species group S) that are present throughout the community. The forb Psilocaulon absimile (species group $\mathrm{S}$ ) are dominant locally.

This community comprises old fields of various ages in different stages of secondary succession. In its natural condition this community formed part of the Panicum maximum-Acacia karroo Woodland (community 5) but has been cleared for cultivation purposes. Once cultivation of these old fields has been discontinued the lands have been left fallow resulting in the increase of pioneer species. Since many of these pioneer grass species (Chloris virgata, Cynodon incompletus, Urochloa panicoides) are palatable it has resulted in the area being overgrazed by Angora goats and sheep previously stocked on the farm. This is evident in the very low veld condition of $19.7 \%$ and grazing capacity of $64.8 \mathrm{ha} / \mathrm{LSU}$. In order for this community to return to its natural condition it is recommended that low stocking rates are applied to this community or that the overgrazed sections are restored to a more acceptable condition.

\section{Discussion}

Plant communities 1 and 2 are located at high altitudes on the escarpment with very steep $\left(25^{\circ}-28^{\circ}\right)$ upper slopes and high rock cover ranging between 50-90\%. Plant communities 3 and 4 are located at medium altitudes with rock cover ranging between 25-60 \%. Plant community 3 is restricted to midslope plateaus, while plant community 4 is mainly located on the lower midslopes and footslopes. The lower footslopes and midslopes are characterised by the Eragrostis obtusa-Pentzia globosa Shrubland (community 6) at medium to low altitudes. Compared to the other communities described within the study area, this major community has a relatively low rock cover varying between $0-30 \%$. The drainage channels are represented by plant communities 5 and 6 . These low-lying communities are situated on more fertile soil with very low rock cover varying between 1-3\%.

This study resulted in the identification of 195 different species representing 112 genera and 38 families being identified in Ingleside-Welgedacht section of the Mountain Zebra National Park. This represents $28 \%$ of all the species and $44 \%$ of all the families previously identified within the park (Pond et al. 2002). The Poaceae has the largest number of species (31) reflecting $16 \%$ of the species of the study area followed by the Asteraceae with 15 species (8\%). These are followed by two much smaller though significant families, the Mesembryanthemaceae and Fabaceae with seven (4\%) and five (3\%) of the species total for the study area.

The largest section of the study area has been overgrazed due to previous farming practices. This has resulted in an overall grazing capacity of $30.1 \mathrm{ha} / \mathrm{LSU}$ for the study area which is high compared to the agricultural norm of 14 ha/LSU for the area. The only communities not affected as much by the previous grazing practices are those situated on the higher lying more inaccessible areas (communities 1, 2 \& 3). In order to improve the veld condition and grazing capacity of the study area it is recommended that the 
area is stocked at well below the carrying capacity for the next few years to ensure stabilisation of the soil and recovery of the vegetation. Restoration of the drainage channels (community 5) and the old fields (community 7) could also be considered. This could be achieved by re-seeding these areas with natural grasses occurring in the area. Field trials at the Doornhoek farm of MZNP yielded good results using a one tooth implement to rip the soil approximately $100 \mathrm{~mm}$ deep and sowing the seeds in the ripped line (pers. obs.). It is also important that no water points are placed in these communities since that would attract more game causing further trampling and overgrazing.

\section{Conclusion}

The Braun-Blanquet approach proved to be an accurate and effective way whereby floristically defined plant communities could be classified and identified in the field. A total of 10 different clearly recognisable plant communities that can be grouped into seven major communities were identified and described for the study area.

No similar vegetation descriptions have previously been completed on the vegetation of the study area and this research therefore provides valuable data on the ecosystems present. An understanding of the plant communities and their associated habitats are of fundamental importance for compiling sound management and conservation strategies. These vegetation surveys and descriptions provide baseline information that allows monitoring as well as similar surveys to be conducted in future. The expansion of MZNP does not only contribute floristically to the diversity of the park but also faunally due to the inclusion of new habitats into the park which make it suitable for the introduction of larger herbivores that occurred historically in this region. The data obtained from this study will therefore be invaluable when compiling a new management plan for the Mountain Zebra National Park as part of a larger project undertaken by UNISA and South African National Parks.

\section{Acknowledgements}

The following individuals and institutions are sincerely thanked: National Research Foundation (NRF) and UNISA for financing this study; SANParks, especially management of Mountain Zebra National Park, for allowing and encouraging the research; Mr Johan de Klerk for his dedication and support of this project; Dr Stephen Holness for the assistance with the maps; $\mathrm{Mr}$ Ernest Daemane (Kimberley South African National Parks Herbarium-KSAN) for verifying the plant species names; and GN Dithlale (UNISA) for assistance with the species data analysis.

\section{References}

AcocKs, J.P.H. 1988. Veld types of South Africa. 3rd ed. Memoirs of the botanical Survey of South Africa 57: 1-146.

Bezuidenhout, H. 1993. Syntaxonomy and synecology of western Transvaal Grasslands. Ph.D dissertation, University of Pretoria, Pretoria.

Bezuidenhout, H. 1996. The major vegetation communities of the Augrabies Falls National Park, Northern Cape. 1. The southern section. Koedoe 39: 7-24.

Bezuidenhout, H., H.C. Biggs, \& G.J. BredenKamp. 1996. A process supported by the utility BBPC for analysing Braun-Blanquet data on a personal computer. Koedoe 39: 107-112.

BREDENKAMP, G.J. 1982. 'n Plantekologiese studie van die Manyeleti-wildtuin. D.Sc. thesis. University of Pretoria, Pretoria.

BREDENKAMP, G.J. \& H. Bezuidenhout. 1995. A proposed procedure for the analysis of large data sets in the classification of South African Grasslands. Koedoe 38(1): 33-39.

Bredenkamp, G.J., A.F. Joubert \& H. BezuidenHOUT. 1989. A reconnaissance survey of the vegetation of the plains in the PotchefstroomFochville-Parys Area. South African Journal of Botany 55: 199-206.

Brown, L.R. \& H. Bezuidenhout. 2000. The phytosociology of the De Rust section of the Mountain Zebra National Park, Eastern Cape. Koedoe 43(1): 1-18.

Brown, L.R. \& G.J BredenKamp. 1994. The phytosociology of the southern section of the Borakalalo Nature Reserve, South Africa. Koedoe 37: 59-72.

BRown, L.R. 1997. A plant ecological and wildlife management plan of the Borakalalo Nature Reserve, North-west Province. Ph.D. dissertation. University of Pretoria, Pretoria.

CARRUTHERS, J. 2003. Changing philosophies \& values. Pp. 23-42. In: South African National 
Parks: a celebration. Hall-Martin, A. \& J. CARRUTHERS (eds.). Singapore: Tien Wah Press.

Cilliers, S.S. 1998. Phytosociological studies of urban open spaces in Potchefstroom, North West Province, South Africa. Ph.D thesis, Potchefstroom University for CHE.

Coetzee, B.J. 1983. Phytosociology, vegetation structure and landscapes of the Central District, Kruger National Park. Dissertationes Botanicae 69: $1-456$.

DANCKWERTS, J.E. 1989. Monitoring vegetation and assessment of veld condition in grassveld. Pp. 96-99. In: Danckwerts, J.E. \& W.R. Teague (eds.). Veld management in the Eastern Cape. Pretoria: Government Printer.

De Klerk, J., Brown, L.R., \& H.Bezuidenhout. 2003. Plant communities of the Ebenaeser section of the Mountain Zebra National Park. Koedoe 46(2): 1-13.

ECKHARDT, H.C. 1993. A synecological study of the vegetation of the north-eastern Orange Free State. M.Sc. thesis. University of Pretoria, Pretoria.

EDWARDS, D. 1983. A broad-scale structural classification of vegetation for practical purposes. Bothalia 14: 705-712.

Foran, B.D., N.M.Tainton \& P. DE V. Booysen. 1978. The development of a method assessing veld conditions in three grassveld types in Natal. Proceedings of the Grassland Society of Southern Africa 13: 27-33.

FuLs, E.R. 1993. Vegetation ecology of the northern Orange Free State. Ph.D. dissertation. University of Pretoria, Pretoria.

Fuls, E.R., G.J. BRedenkamp, \& N VAN RoOyen. 1992. The plant communities of the undulating grassland of the Vredefort-Kroonstad-Lindley-Heilbron area, northern Orange Free State. South African Journal of Botany 58: 224-230.

Germishuizen, G. \& N.L. Meyer (eds). 2003. Plants of southern Africa: an annotated checklist. Pretoria: National Botanical Institute. (Strelitzia 14).

Hall-Martin, A. 2003. South Africa's biodiversity. Pp. 1-19. In: South African National Parks: a celebration. Hall-Martin, A. \& J. CARRUTHers (eds.). Singapore: Tien Wah Press.

HILL, M.O. 1979. TWINSPAN-A FORTRAN program for arranging multivariate data in an ordered twoway table by classification of the individuals and attributes. New York: Cornell University.

Hoffman,T. 1996. Eastern Mixed Nama Karoo. P. 55. In: Low, A.B. \& A.G. ReBelo (eds.). Vegetation of South Africa, Lesotho and Swaziland. Pretoria: Department of Environmental Affairs \& Tourism.

KoolJ, M.S., G.J. BredenKamp \& G.K. Theron. 1990. Classification of the vegetation of the $B$ land type in the north-western Orange Free
State. South African Journal of Botany 56: 309-318.

Land Type Survey Staff. 1986. Land types of the maps SE27/20 Witdraai, 2720 Noenieput, 2722 Kuruman, 2724 Christiana, 2820 Upington, 2822 Postmasburg. Memoirs on the Agricultural Natural Resources of Southern Africa 3: 1-185.

Land Type SuRvey StafF. 1999. Land types occurrence (maps) and areas of 3224 Graaff-Reinet. Unpublished information obtained from Institute for Soil, Climate and Water, Pretoria.

Lubke, R., G.J. Bredenkamp \& N. VAn Rooyen. 1996. South-eastern Mountain Grassland. P. 55. In: Low, A.B. \& A.G. ReBelo (eds.). Vegetation of South Africa, Lesotho and Swaziland. Pretoria: Department of Environmental Affairs \& Tourism.

Mueller-Dombois, D. \& H. Ellenberg. 1974. Aims and methods of vegetation ecology. New York, NY: Wiley.

Mucina, L. \& E. VAn DeR MaARel. 1989. Twenty years of numerical syntaxonomy. Vegetatio 81 : $1-15$.

NovelLie, P. 1990a. Habitat use by indigenous grazing ungulates in relation to sward structure and veld condition. South African Journal of Wildlife Research 7: 16-23.

Novellie , P. 1990b. The impact of a controlled burn on Karroid Merxmuellera mountain veld in the Mountain Zebra National Park. South African Journal of Ecology 1: 33-37.

Novellie, P.A. \& H. Bezuidenhout. 1994. The influence of rainfall and grazing on vegetation changes in the Mountain Zebra National Park. South African Journal of Wildlife Research 24: 60-71.

Pond, U., B.B. Beesley, L.R. Brown \& H. Bezuidenhout. 2002. Floristic analysis of the Mountain Zebra National Park, Eastern Cape. Koedoe 45(1): 35-57.

OrBAN, B. 1995. An ecological management plan for the Lionspruit Game reserve. M.Sc. (Wildlife Management) dissertation. University of Pretoria, Pretoria.

SMIT, G.N. 1988. Die invloed van langtermyn graslaag benuttingspraktyke op die suurgemengde Bosveld. M.Sc. dissertation. University of Pretoria, Pretoria.

Soil Classification Working Group. 1991. Soil classification: a taxonomic system for South Africa. Memoirs on the Agricultural Natural Resources of South Africa 15: 1-262.

Toerien, D.K. 1972. Geologie van die Bergkwagga Nasionale Park. Koedoe 15: 77-82.

Trollope, W.S.W., L. Trollope \& O.J.H. Bosch. 1990. Veld and pasture management terminology in Southern Africa. Journal of the Grassland society of Southern Africa 7: 52-61. 
TUELLER, P.T. 1988. Vegetation science applications for rangeland analysis and management. Dordrecht: Kluwer Academic Publishers.

VAN DER WALT, P.T. 1980. A phytosociological reconnaissance of the Mountain Zebra National Park. Koedoe 23: 1-32.

VAN OUDTSHOORN, F.P. 1992. Guide to grasses of South Africa. Arcadia, Pretoria: Briza.

Van Rooyen, N., G.K. Theron \& N. Grobbelaar. 1981. A floristic description and structural analysis of the plant communities of the Punda Milia-Pafuri-Wambiya area in the Kruger National Park, Republic of South Africa. 1. The hygrophilous communities. South African Journal of Botany 47: 213-246.

VORSTER, M. 1982. The development of the ecological index method for assessing veld condition in the Karoo. Proceedings of the Grassland Society of Southern Africa 17: 84-89.

Westhoff, V. \& E. Van Der Maarel. 1978. The Braun-Blanquet approach. Pp. 287-399. In: WhitTAKeR, R.H. (ed.). Classification of plant communities. The Hague: Junk.

Whittaker, R.H. 1978. Dominance types. Pp. 65-79. In: WhitTAKER, R.H. (ed.). Classification of plant communities. The Hague: Junk. 